\title{
WATER SORPTION AND SOLUBILITY OF DIFFERENT CALCIUM HYDROXIDE CEMENTS
}

\author{
Luciana Fávaro FRANCISCONI ${ }^{1}$, Anderson Pinheiro de FREITAS ${ }^{2}$, Polliana Mendes Candia SCAFFA ${ }^{3}$, \\ Rafael Francisco Lia MONDELLI ${ }^{4}$, Paulo Afonso Silveira FRANCISCONI ${ }^{4}$
}

\author{
1- DDS, MSc, PhD Student, Department of Operative Dentistry, Endodontics and Dental Materials, Bauru Dental School, University of São Paulo; \\ Bauru, SP, Brazil. \\ 2- DDS, MSc, PhD, Adjunct Professor, Department of Dental Clinics, Dental School, Federal University of Bahia, Salvador, BA, Brazil. \\ 3- DDS, MSc, PhD Student, Department of Restorative Dentistry, Dental Materials Area, Piracicaba School of Dentistry, University of Campinas; \\ Piracicaba, SP, Brazil. \\ 4- DDS, MSc, PhD, Associate Professor, Department of Operative Dentistry, Endodontics and Dental Materials, Bauru Dental School, University of \\ São Paulo; Bauru, SP, Brazil.
}

Corresponding address: Luciana Fávaro Francisconi - Departamento de Dentística, Endodontia e Materiais Dentários, FOB/USP - Alameda Dr. Octávio Pinheiro Brisolla, 9-75 - Cx Postal 73, 17012-901, Bauru, SP, Brazil - Phone: 551432358263 - Fax: 551432261495 - e-mail: luff@usp.br

Received: July 7, 2008 - Modification: August 31, 2008 - Accepted: October 7, 2008

\begin{abstract}
$O$

bjectives: Calcium hydroxide cements have been largely used in deep cavities due to their abilities to stimulate dentin formation. However, their resistance can be relatively low and their solubility relatively high, in many instances. This study evaluated water sorption and solubility of different calcium hydroxide cements, in order to show alterations that may reduce their effectiveness. Material and methods: Five discs $\left(20 \mathrm{~mm}\right.$ in diameter and $1.5 \mathrm{~mm}$ thick) of three different materials (Biocal ${ }^{\circledR}$, Dycal $^{\circledR}$ and Hidro $^{\circledR}$ ) were prepared with the aid of a ring-shaped metallic matrix. After being stored at $37^{\circ} \mathrm{C}$ for $24 \mathrm{~h}$, the discs were weighed on a precision weight scale, dehydrated and weighed again. Immediately after weighing, discs were stored for a week in $50 \mathrm{~mL}$ of distilled water at $37^{\circ} \mathrm{C}$ and, then, weighed again, dehydrated and submitted to a new weighing. The loss of soluble material and its water sorption was obtained from the difference between the initial and the final dry mass of each disc, after 1 week of immersion in water. Data were analyzed for significant differences by two-way ANOVA and Tukey's test $(p<0.05)$. Results: Mean water sorption values $(\mathrm{g}) \pm$ standard deviation and percentage (\%), for each evaluated cement, were: Biocal ${ }^{\oplus}(0.006 \pm 0.001 / 2.15)$; $\operatorname{Dycal}^{\circledR}(0.016 \pm 0.004 / 5.49)$; and Hidro $C^{\circledR}(0.025 \pm 0.003 / 8.27)$. Mean solubility values $(\mathrm{g}) \pm$ standard deviation and percentage (\%), for each evaluated cement, were: Biocal ${ }^{\circledR}(0.002 \pm 0.001 / 0.72)$; Dycal $^{\circledR}(0.013 \pm 0.004 / 4.21)$; and Hidro $\mathrm{C}^{\circledR}(0.023 \pm 0.004$ 1 7.65). Conclusions: Biocal ${ }^{\circledR}$ absorbed less water and was less soluble than the other evaluated cements; Hidro $\mathrm{C}^{\circledR}$ exhibited the highest water sorption and solubility values; and there were significant differences among all evaluated experimental groups.
\end{abstract}

Key words: Dental cements. Calcium hydroxide. Solubility. Water sorption.

\section{INTRODUCTION}

Hermann suggested in 1920 that materials containing calcium hydroxide had an important use as bases and cavity liners ${ }^{2,18}$. Their indications include favoring pulp healing after injury by caries and/or operational procedures as well as protecting the pulp against the penetration of components of restorative materials and oral substances ${ }^{11,16-18}$. Additionally, calcium hydroxide cements have been largely used in deep cavities because of their capacity to stimulate dentin formation ${ }^{1,5,6,8,11,14}$.

More recently, manufacturers have produced resin-based calcium containing materials with superior physical properties when compared to cements without resin components. These materials are cured by visible light ${ }^{7}$ and are highly resistant to etchants ${ }^{2}$.
Although hard-setting calcium hydroxide cements may induce the formation of dentin bridges, they are not likely to provide an effective long-term seal when facing bacterial challenge. Within a few years, the majority of mechanically exposed and capped pulps show infection and necrosis caused by microleakage of such capping materials and tunnel defects in the dentin bridges ${ }^{13,17}$. Strength properties of these cements are relatively low and solubility is relatively high in many instances ${ }^{15}$.

Several cases are mentioned in the literature in which base/liner materials, after some time, are not capable to remain stable under restorations, leaving the cavity without protection and the restoration without support, which may be caused by the material's dissolution or water sorption. This may occur when the material get in contact with either dentinal fluid, which is more common in freshly prepared 
cavities, or aqueous medium, that is, due to marginal infiltration or hydrolytic decomposition ${ }^{4,9,10,13}$.

These points suggest that the lining permanence between the tooth and the restoration is of particular importance. Moreover, material solubilization, or its water sorption, may be directly related to the loss of its properties. In addition, the resistance of calcium hydroxide cements to disintegration has been an important criterion to evaluate the quality of these materials ${ }^{3}$.

It is unknown whether relative newer types of resin containing calcium hydroxide cements will act as a permanent barrier. Based on these data, pulp capping with resin-based cements may look promising, but, in fact, more research is necessary to provide a valuable confirmation ${ }^{13}$. Taking these aspects into account, it seems interesting to evaluate the behavior of different calcium hydroxide cements regarding their water sorption and solubility properties, in order to show possible alterations that may be present after some time, which reduce their effectiveness. Three commercial brands of calcium hydroxide cements were evaluated: one resin-modified light curing cement and two chemically activated cements that are mainly used in the Brazilian clinical practice.

\section{MATERIAL AND METHODS}

The American Dental Association's specification \#8 (zinc phosphate cement solubility) was adopted with a few small modifications to design the methodology used in this study: the solubility tests used distilled water rather than oral fluids for immersion of specimens, and the specimens were stored for 1 week ${ }^{3}$.

For the solubility tests, 5 disc-shaped specimens $(20 \mathrm{~mm}$ diameter x $1.5 \mathrm{~mm}$ thick) of each material $\left(\right.$ Biocal $^{\circledR}$, Dycal ${ }^{\circledR}$ and Hidro $C^{\circledR}$ - Figure 1) were prepared (Figure 2). The mixing of the two pastes of each material was carried out according to the manufacturers' instructions, using standardized techniques, in a 1:1 weight proportion, in a room with climate-controlled conditions $(50 \pm 10 \%$ humidity and $23 \pm 2^{\circ} \mathrm{C}$ ).

For fabrication of the specimens, a metallic ring matrix with a 20 -mm-diameter and 1.5 -mm-thick central perforation was placed onto a polyester strip placed on a glass plate. The perforation was filled with the calcium hydroxide cement using a Centrix injector and the matrix was covered with a polyester strip and a glass plate, which were maintained under finger pressure until the complete setting of the material (Figures 3 and 4). A dental floss was embedded in each disc in order to help handling the

\begin{tabular}{|c|c|c|c|c|}
\hline Cement & Composition & Activation & Batch \# & Manufacturer \\
\hline Biocal $^{\circledR}$ & $\begin{array}{c}\text { Calcium ( } 3.53 \%) \text {, ethylene urethane } \\
\text { dimethacrylate, inorganic fillers, barium } \\
\text { sulfate, photoactivator, titanium dioxide and } \\
\text { iron oxide. }\end{array}$ & Physical (Light) & $\begin{array}{c}2007-11 \\
990 / 05\end{array}$ & $\begin{array}{l}\text { Biodinâmica } \\
\text { Ibiporã, PR, Brazil }\end{array}$ \\
\hline Dycal $^{\circledast}$ & $\begin{array}{c}\text { Base paste: } \\
\text { 1,3-Butylene glycol disalicylate } \\
\text { Zinc oxide } \\
\text { Calcium phosphate } \\
\text { Calcium tungstate } \\
\text { Iron oxide pigments } \\
\text { Catalyst paste: } \\
\text { Calcium hydroxide } \\
\text { N-ethyl-o/p-toluene sulfonamide } \\
\text { Zinc oxide } \\
\text { Titanium dioxide } \\
\text { Zinc stearate } \\
\text { Iron oxide pigments (dentine shade only) }\end{array}$ & Chemical & 516291 & $\begin{array}{c}\text { Dentsply Indústria e } \\
\text { Comércio Ltda, Petrópolis, } \\
\text { RJ, Brazil }\end{array}$ \\
\hline Hidro $\mathrm{C}^{\circledR}$ & $\begin{array}{c}\text { Base paste: } \\
\text { Ester glycol salicilate } \\
\text { Zinc oxide } \\
\text { Calcium phosphate } \\
\text { Calcium tungstate } \\
\text { Pigments } \\
\text { Catalyst paste: } \\
\text { Calcium hydroxide } \\
\text { N-ethyl-o/p-toluene sulfonamide } \\
\text { Zinc oxide } \\
\text { Titanium dioxide } \\
\text { Zinc stearate } \\
\text { Pigments }\end{array}$ & Chemical & 160216 & $\begin{array}{c}\text { Dentsply Indústria e } \\
\text { Comércio Ltda, Petrópolis, } \\
\text { RJ, Brazil }\end{array}$ \\
\hline
\end{tabular}

FIGURE 1 - Calcium hydroxide cements used in this study 


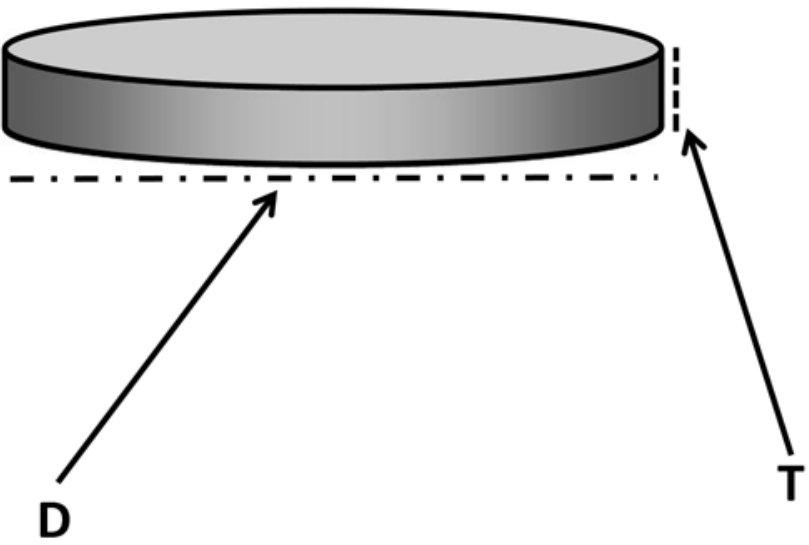

FIGURE 2- Dimensions of the specimens [Diameter (D)= $20 \mathrm{~mm}$; thickness $(\mathrm{T})=1.5 \mathrm{~mm}$ ]

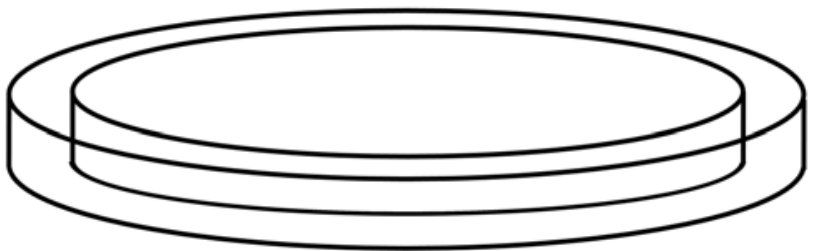

FIGURE 3- Metallic ring matrix with a 20-mm-diameter and 1.5-mm-thick central perforation, which was filled with the calcium hydroxide cements

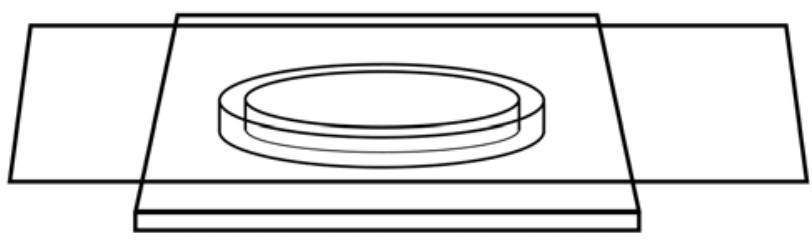

FIGURE 4- Matrix covered with a polyester strip and a glass plate, which were maintained under finger pressure until the complete setting of the cements

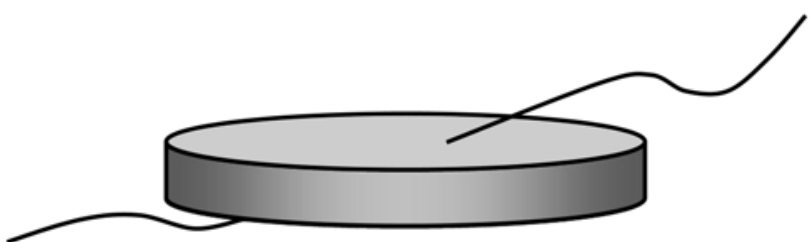

FIGURE 5- Dental floss embedded in the cement disc to help handling the specimens

specimens (Figure 5). The disc-shaped specimens were immersed in distilled water and stored at $37^{\circ} \mathrm{C}$. After $24 \mathrm{~h}$, the specimens were weighed on a precision scale, dehydrated in an oven at $37^{\circ} \mathrm{C}$ for $1 \mathrm{~h}$ and weighed again.

Immediately after weighing, the discs were stored in individual flasks containing $50 \mathrm{~mL}$ of distilled water at $37^{\circ} \mathrm{C}$ during 1 week (Figure 6), and weighed and dehydrated again, as mentioned above, and subjected to a new weighing.

The loss of soluble material was obtained from the difference between the initial and the final drying mass of

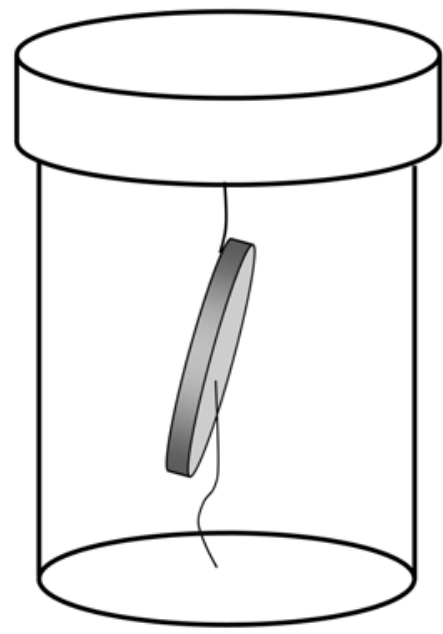

FIGURE 6- Disc stored in distilled water

each disc, discounting the mass of the ring-dental floss unit. The water sorption was obtained from the difference between the wet and the dry mass of each disc, and from another weighing after 1 week immersion in water.

The water sorption and solubility values obtained for each material were analyzed statistically by two-way ANOVA and Tukey's tests at 5\% significance level.

\section{RESULTS}

Biocal ${ }^{\circledR}$ showed the lowest water sorption $(2.15 \%)$ and differed significantly from the other materials. Dycal ${ }^{\circledR}$ showed intermediary water sorption values $(5.49 \%)$ and Hidro $\mathrm{C}^{\mathbb{R}}$ showed the highest values $(8.27 \%)$ (Table 1$)$

TABLE 1- Water sorption mean values (in g) \pm standard deviation and percent water sorption $(n=5 ; p<0.05)$

\begin{tabular}{lcc}
\hline Cement & Mean* $^{*}$ standard deviation & $\%$ \\
\hline Biocal $^{\circledR}$ & $0.006^{\mathrm{a}} \pm 0.001$ & 2.15 \\
Dycal $^{\circledR}$ & $0.016^{\mathrm{b}} \pm 0.004$ & 5.49 \\
Hidro C $^{\circledR}$ & $0.025^{\mathrm{c}} \pm 0.003$ & 8.27 \\
\hline
\end{tabular}

*Different letters indicate statistically significant differences $(p<0.05)$.

TABLE 2- Solubility mean values (in g) \pm standard deviation, and solubility percentage $(n=5 ; p<0.05)$.

\begin{tabular}{lcc}
\hline Cement & Mean $^{*} \pm$ standard deviation & $\%$ \\
\hline Biocal $^{\circledR}$ & $0.002^{\mathrm{a}} \pm 0.001$ & 0.72 \\
Dycal $^{\circledR}$ & $0.013^{\mathrm{b}} \pm 0.004$ & 4.21 \\
Hidro C $^{\circledR}$ & $0.023^{\mathrm{c}} \pm 0.004$ & 7.65 \\
\hline
\end{tabular}

*Different letters indicate statistically significant differences $(p<0.05)$. 
Biocal $^{\circledR}$ showed the lowest solubility $(0.72 \%)$, after water immersion for 1 week, and differed significantly from the chemically activated cements. Dycal ${ }^{\circledR}$ showed intermediary solubility (4.21\%) and Hidro $\mathrm{C}^{\circledR}$ presented the highest solubility $(7.65 \%)$. (Table 2$)$

The water sorption values showed correlation with the solubility values: the higher the water sorption, the greater the solubility for the evaluated materials.

\section{DISCUSSION}

According to Tam, et al. ${ }^{15}$, high strength and low solubility are desirable for any base or lining material. A strong base material is needed to support the overlying restoration and the subsequent occlusal forces acting upon it during clinical function. Some reduction observed in compressive strength may be attributed to dissolution or water sorption during storage. Moreover, marginal infiltration may influence on liners hardness, which reinforces the need for studies related to their physical properties.

This study was aimed at elucidating essential values for the evaluation of the quality of each employed material, which is of important clinical applicability. In fact, lining and base materials have to be resistant to dissolution in water, organic solvents and acid-etching solutions, in order to maintain their pulp protective effect ${ }^{16}$. In addition, dissolved and smeared calcium hydroxide may contaminate acidetched enamel, and produce an inferior bond, which is not desirable ${ }^{10}$.

The choice for the three kinds of cements here evaluated was based on the fact that Dycal ${ }^{\circledR}$ and Hidro $C^{\circledR}$ are the most commonly used conventional lining materials, in the clinical practice. Biocal ${ }^{\circledR}$ was used in this study because it is a resinbased calcium hydroxide cement, easily found on the market. Its main advantage, according to the manufacturer, is to present less solubility and water sorption, which improves its physical properties and, consequently, increases its longevity when it is used under restorations.

Water sorption and solubility tests were applied according to the ADA's \#8 specification, though with few alterations to meet the objectives of this study. This modified methodology has been successfully used in previous studies on pulp capping materials ${ }^{1,3}$.

However, the results obtained in laboratorial studies must be carefully applied to the clinical conditions since calcium hydroxide cement bases are significantly more soluble in distilled water than in simulated dentinal fluid or saliva used in other studies. Likewise, the length of time specified by ADA solubility test (1 week) does not seem to be adequate for testing lining materials, as they continue to dissolve in the next 3 months ${ }^{3}$.

Although pulp-capping materials look similar as far as mixing and composition are concerned, in that they are essentially calcium hydroxide and an ester of salicylic acid, Posser, et al. ${ }^{12}$ have shown that there are several important differences in their components. The present study showed that the differences in the basic composition of the evaluated cements, that is, the presence or absence of resin particles, determined and influenced positively Biocal ${ }^{\circledR}$ behavior, a resin-modified light-cured material. This cement (Biocal ${ }^{\circledR}$ ) showed lower solubility and less water sorption, after 1week immersion in distilled water when compared with chemically activated cements (Dycal ${ }^{\circledR}$ and Hidro $C^{\circledR}$ ).

Similar results have been reported by Burke and Watts ${ }^{2}$, where resin-based lining materials proved to have better resistance than conventional calcium hydroxide cements, even if further clinical properties of those materials, such as their polymerization shrinkage, still need to be investigated.

It is important to emphasize that the results of the present study cannot be extrapolated to conditions others than the ones described here. A base material should be relatively insoluble and have great strength. Nevertheless, if a base material is to be selected for its biological properties, it should present some degree of dissolution at the vital dentinbase interface. If this material is relatively insoluble, ion exchange with the odontoblastic layer may be hindered, and consequently the amount of secondary dentin is reduced and its main indication is questionable ${ }^{3}$.

\section{CONCLUSIONS}

On the basis of this study, it may be concluded that: 1Biocal ${ }^{\mathbb{R}}$ absorbed less water and is less soluble than the other evaluated cements; 2- Hidro $C^{\circledR}$ showed the highest water sorption and solubility rates; and 3 - There were significant differences among the tested materials.

\section{ACKNOWLEDGEMENTS}

This study was partly supported by SESu/MEC (PETBrazil). The authors are indebted to Prof. José Roberto Pereira Lauris for his assistance with the statistical analysis.

\section{DISCLOSURE}

The authors have no financial interest in the companies that supplied the tested materials.

\section{REFERENCES}

1- Burke FJT, Watts DC. Weight loss of four calcium hydroxide-based materials following a phosphoric acid etching and washing cycle. J Dent. 1986;14(5):226-7.

2- Burke FJT, Watts DC. Weight loss of three resin-based lining materials containing calcium following a phosphoric acid-etching and washing cycle. J Dent. 1989;17(1):38-40.

3- Driscoll CF, Woolsey GD, Reddy TG, Craig RG. Solubility of zinc oxideeugenol and calcium hydroxide cements in simulated dentinal fluid. $\mathrm{J}$ Oral Rehabil. 1989;16(5):451-5. 
4- El-Araby A, Al-Jabab A. The influence of some dentin primers on calcium hydroxide lining cement. J Contemp Dent Pract. 2005;6(2):1-9.

5- Hebling J, Giro EM, Costa CA. Human pulp response after an adhesive system application in deep cavities. J Dent. 1999;27(8):557-64.

6- Hörsted-Bindslev P, Vilkinis V, Sidlauskas A. Direct capping of human pulps with a dentin bonding system or with calcium hydroxide cement. Oral Surg Oral Med Oral Pathol Oral Radiol Endod. 2003;96(5):591600 .

7- Kitasako Y, Shibata S, Tagami J. Migration and particle clearance from hard-setting $\mathrm{Ca}(\mathrm{OH}) 2$ and self-etching adhesive resin following direct pulp capping. Am J Dent. 2006;19(6):370-5.

8- Murray PE, About I, Franquin JC, Remusat M, Smith AJ. Restorative pulpal and repair responses. J Am Dent Assoc. 2001;132(4):482-91.

9- Perotti R, Brondino D, Corteletti C, Pagliaro S. The compression resistance and water solubility of self-hardening cements of calcium hydroxide. Minerva Stomatol. 1990;39(12):1059-61.

10- Phillips RW, Crim G, Swartz ML, Clark HE. Resistance of calcium hydroxide preparations to solubility in phosphoric acid. J Prosthet Dent. 1984;52(3):358-60.

11- Pinto AS, Araújo FB, Franzon R, Figueiredo MC, Henz S, GarcíaGodoy $\mathrm{F}$, et al. Clinical and microbiological effect of calcium hydroxide protection in indirect pulp capping in primary teeth. Am J Dent. 2006;19(6):382-6.

12- Posser HJ, Grossman DM, Wilson AD. The effect of composition on the erosion properties of calcium hydroxide cements. J Dent Res. 1982;61(12):1431-5

13- Schuurs AH, Gruythuysen RJ, Wesselink PR. Pulp capping with adhesive resin-based composite vs. calcium hydroxide: a review. Endod Dent Traumatol. 2000;16(6):240-50.

14- Souza Costa CA, Nascimento ABL, Teixeira HM, Fontana UF. Response of human pulps capped with a self-etching adhesive system. Dent Mater. 2001;17(3):230-40.

15- Tam LE, Pulver E, McComb D, Smith DC. Physical properties of calcium hydroxide and glass-ionomer base and lining materials. Dent Mater. 1989;5(3):145-9.

16- Von-Fraunhofer JA, Marshall KR, Holman BG. The effect of base/ liner use on restoration leakage. Gen Dent. 2006;54(2):106-9.

17- Ward J. Vital pulp therapy in cariously exposed permanent teeth and its limitations. Aust Endod J. 2002;28(1):29-37.

18- Weiner RS. Liners, bases, and cements: a solid foundation. Gen Dent 2002;50(5):442-6. 